\title{
Transforming the Reading Preferences of Today's Youth in the Digital Age: Intercultural Dialog
}

\author{
Olga Shatunova \\ Kazan (Volga Region) Federal University, Russia \\ Galina Bozhkova \\ Kazan (Volga Region) Federal University, Russia \\ Bulent Tarman ${ }^{1}$ \\ Independent Researcher, Turkey \\ Elena Shastina \\ Kazan (Volga Region) Federal University, Russia
}

\begin{abstract}
The article deals with the transformation of readers' preferences and the formation of a "new reader" at the end of the 20th and beginning of the 21 st century. In the study, the authors draw attention to the shift in the priority of the format of youth reading in favor of digital, to the loss of the former role of libraries as centers of non-formal education, as well as to the need to provide assistance to children and young people on the part of "teacher of literature". An international study undertaken in Russia, the U.S., and the Czech Republic touches upon socio-cultural changes that influenced the reading process among the youth of these countries and the particular interest of the analyzed age group in the fantasy genre, which indicates a change in the reading preferences of young people and the need for understanding this process both in theoretical aspects and taking into account the results of empirical research. The authors conclude that it is advisable to determine the scale of values of a modern person by means of literary pedagogy, to bring it to a common denominator in the intercultural space. As the leading genre of revealed reader preferences, fantasy is becoming a multimedia phenomenon and is shifting the age boundaries of potential readers around the world.
\end{abstract}

Keywords: intercultural communication, intercultural dialogue, digitalisation, reading literacy, socialisation of personality.

In recent decades, the problem of the decreasing readership of adolescents and young people has been increasingly considered, taking into account all kinds of transformational phenomena characteristic of the modern socio-cultural situation, in general, and for the reading sphere, in particular (Bailey, 2016; Broeder \& Stokmans, 2013; Pontier, Destro Boruchowski, \& Olivo, 2020). This "requires identifying and systematizing the key incentives for enhancing reading activity," taking into account the demands and preferences formed in the conditions of the changed reality (Askarova \& Zubanova, 2018, p. 93). Naturally, digitalization in almost all spheres of life has led to the emergence of a "new" type of reader with a high level of computer literacy, on the

${ }^{1}$ Corresponding Author E-Mail: btarman@gmail.com 
one hand, and an insufficient level of reading literacy, on the other hand, due to the displacement of traditional book reading (Gudova, 2015; Shastina et al., 2018). "Screen information," for the most part, is clip-like in nature, violating the "conceptual unfolding of a text sequence," and this leads to an "increasing superficiality when reading literary texts" (Nazarov \& Kovalev, 2017, p. 91). Since young people get used to working with digests, information extracts that offer only familiarity with the plot of a literary text, "forgetting about the semantic depths of the language" (Petrovskaya, 2012, p. 98), scientists are looking for ways out of this situation, paying attention not only to the disadvantages but also to the advantages of transforming readers' contact with printed text (Fortunati \& Vincent, 2014; Jeong, 2012; Mozhaeva, 2015; Rubanova, 2018; Timberlake, 2020; Vershitskaya, 2007; Wilson, 2014).

The transformation of a reader into a so-called "screen reader" is associated with a number of problems that require examining the existing international experience and the possibility of its use in intercultural communication (Başok \& Soyer, 2020; Jeong, 2012; Fortunati \& Vincent, 2014; $\mathrm{Vu}, 2019)$. This will allow future consideration of reading as one of the most important factors of intercultural communication, taking into account the existing differences (interfaith, ethnic, etc.) (Lehman \& Welch, 2020; Masud, 2020; Salinas-Vasquez, et al., 2020; Velagić, 2014).

The authors of this study proceed from the fact that a change in the reading format (from paper to screen) entailed a change in the form of leisure, since the library as a traditional place of leisure has lost its significance. Being "alone with a computer" has generally affected the communication mechanisms of young people, when live communication about what is read is reduced, at best, to participation in an Internet forum (Lensky, 2011; Rubanova, 2018).

At the same time, it seems important to grasp the moods of young people, to understand their life aspirations, which are not formed without the influence of the literary context (Smetannikova, 2017). The change in reading preferences of youths is inextricably linked not only with internal political events but also, in general, with the international situation, since literature cannot ignore paradigmatic shifts in public consciousness (Gaffney \& Anderson, 2000; Johnson, 2020). For instance, the cult novel of American youth of the 1960s, J. D. Salinger's "The Catcher in the Rye," tells the story of a 16-year-old boy's heightened perception of American reality and rejection of the general canons and morality of modern society. In the Soviet Union, the youths of this period read the novels of German writer Erich Maria Remarque and American writer Ernest Hemingway, who proposed a model of society different from the Soviet reality.

The literary-centric model of society that took place in Europe, the United States, and the Soviet Union lasted until the 1970s and 1980s. In the United States, the "departure" from traditional reading occurred in the 1980s and 1990s (Bailey, 2016; Elley, 1992; Gaffney \& Anderson, 2000; Morales \& Bardo, 2020; Smetannikova, 2017) due to the emergence of a new reading format as well as a rise in the cost of printing products. The displacement of traditional reading in Russian society occurred later: During the Perestroika period, there was a certain rise in readers' interest, associated with the availability of books by authors that had not previously been published for ideological reasons (Gudova, 2015; Boshkova et al., 2018).

In the modern era of globalization and complex geopolitical situations, it seems important to search for new forms of work that contributes to building an intercultural dialogue. The fantasy genre has become iconic not only among children and youths, and it was chosen as literature "understandable" for young people from different countries with a fairly high level of development in the book market (Brevnova, 2005; Gibbs, 2020; Pomogalova, 2006). One of the most popular series in this genre is the Harry Potter series by British writer J. K. Rowling (Alexandrov, 2001; Ammosov, 2005; Bell, 2010; Black, 2003; Campbell, 2010; Firestone \& Clark, 2018; Lerer, 2008; Vasilieva, 2005; Vinogradova, 2003). The issue of the place and significance of fantasy in the 
modern literary process is debatable. Fantasy is compared with the "epidemic of infantilism" that has swept modern society; fantasy works are accused of escapism, an obvious commercial component is noted, and there is an abundance of templates and clichés. At the same time, there is an opposite point of view, indicating that the quality of the work does not depend on the genre (Winterle, 2013).

Since the end of the 1990s, the books about Harry Potter have become bestsellers in the Russian book market. The time of political and economic instability has become fertile ground for the flourishing of the fantasy genre in Russia. The story is popular because the reader, immersed in the world of fantastic reality, is open to the world of illusions, leading to creative imagination and creative thinking. The presence of folklore and mythological motifs leads to the heroization of characters fighting evil in all its manifestations - in the family, society, school, etc. - which seems significant for young readers in search of the meaning of life and the pursuit of the ideal (Vasilieva, 2005). All this affects the socialization of the young generation and contributes to their intellectual development (Bekteshi \& Xhaferi, 2020; Elley, 1992; Gaffney \& Anderson, 2000; GarroneShufran \& Tannebaum, 2020; Moody, 2020; Stacy, Fernández, \& Reyes McGovern, 2020).

\section{Methods}

To solve the tasks set in the work, a set of methods was applied, theoretical and empirical, complementing and concretizing each other, which made it possible to expand and systematize scientific facts, increase the reliability of the results obtained empirically, and move from abstract to concrete knowledge concerning the study of reading among children and adolescents in Russia, the Czech Republic, and the United States. For this, questionnaires were used, during the processing of which the methods of statistical and correlation analysis were applied, as well as content analysis. The systematic method contributed to the consideration of the phenomenon of reading as a unity of the means of socialization and intercultural communication. The experience of reception of fantasy literature in different countries was described and generalized using a typological and comparative cultural approach.

In total, the study involved 408 university students aged 18 to 27: 208 Russian youths (47 boys and 161 girls), 89 Americans (51 boys and 48 girls), and 111 respondents from the Czech Republic (75 boys and 36 girls). Male respondents made up $42.4 \%$ and female respondents $57.6 \%$ of the total number of survey participants. The choice of these three countries as the base of the study is explained by the close intercultural ties of the authors of the article with colleagues from the United States and the Czech Republic, who helped to conduct the survey. The long-term exchange of students leaving for internships from the U.S., Russia, and the Czech Republic allows the maintenance of friendly relations between the Kazan Federal University (Russia), West Bohemian University (Czech Republic), and Ferris State University, Michigan (U.S.).

Among Russian respondents, the sample included representatives of the following nationalities and peoples: Russians, Tatars, Udmurts, Maris, Chuvashes, Turkmens, and Tajiks. The sample of American respondents included students from China (Macau), Saudi Arabia, the U.S. (Detroit, Chicago, and Grand Rapids, Michigan), Great Britain, India, and Holland. The Czech Republic was represented by the inhabitants of the city of Pilsen, belonging to the region of Bohemia. The questionnaires for the survey in the United States and the Czech Republic were translated into English and Czech and presented to the respondents in a paper form by the authors' colleagues from Ferris State University (U.S.) and the University of West Bohemia (Czech Republic).

In the questionnaire, the following questions were presented (Table 1): 


\section{Table 1}

Questionnaire About the Issue of Reading

\begin{tabular}{cl}
\hline No. & Questions \\
\hline 1 & How often do you read books? \\
2 & What are your motives for reading? \\
3 & Which literary genres do you prefer to read? \\
5 & Which reading format do you prefer? \\
\hline
\end{tabular}

\section{Results}

The main purpose of the questionnaire was to clarify the question of how similar or different the reading preferences of young people are in different countries. In particular, the authors were interested in the respondents' attitudes toward the genre of fantasy. It should be noted that in all the chosen countries, there is a large number of representatives of various peoples having differences in language, culture, traditions, and religion.

For example, a large number of different ethnic groups live in the United States. According to a Russian-language online encyclopedia about the U.S. at www.prousa.info, the largest ethnic (national) population groups in the United States include Germans (49 million people, 15\% of the total population of the country), African Americans (42 million people, 13\%), Mexicans (36 million people, 11\%), Irish (32 million people, 10\%), British (26 million people, $8 \%$ ), and Italians (20 million people, 6\%).

The total population of the Czech Republic as of 2019 is 10.6 million people. Among the largest ethnic groups of the population of the Czech Republic are Czechs (8.5 million people, $80 \%$ of the total population of the country), Moravians (1.4 million people, $13.5 \%)$, Slovaks $(0.15$ million people, 1.15\%), and Ukrainians (0.15 million people, $1.15 \%)$ (https://zagranportal.ru/chehiya/zhizn-chehiya/nacionalnosti-i-etnicheskie-gruppy.html).

Currently, 146 million people live in Russia. The most numerous ethnic groups of the population are Russians (111.2 million people, $77.7 \%$ of the total population of the country), Tatars (5.2 million people, 3.7\%), Ukrainians (2 million people, 1.35\%), Bashkirs (1.6 million people, $1.1 \%)$, Chuvash (1.5 million people, $1 \%)$, Chechens (1.5 million people, $1 \%)$, and Armenians (1.2 million people, $0.8 \%$ ) (https://rosinfostat.ru/natsionalnyj-sostav/).

The survey participants from Russia were mainly residents of the Republic of Tatarstan, one of the constituent entities of the Russian Federation, in which about 4 million people live (ranking 8th in terms of population). Tatarstan is one of the most multinational territories in Russia; representatives of over 173 nationalities live there. The most numerous peoples, according to 2010 data, are Tatars (1.98 million people, $52.4 \%$ of the total population of the republic), Russians (1.5 million people, 39.6\%), and Chuvash (0.12 million people, 3.1\%) (http://tatarcongress.org/ru/yanalyklar/natsionalnyy-sostav/).

When processing the results of our survey, we accounted for the fact that our respondents were young people belonging to different peoples and nationalities.

To the question "How often do you read fiction?" we received the following answers (Figure 1). Data are shown as a percentage of the total number of survey respondents from each country. 


\section{Figure 1}

Regularity of Reading in the Czech Republic, U.S., and Russia

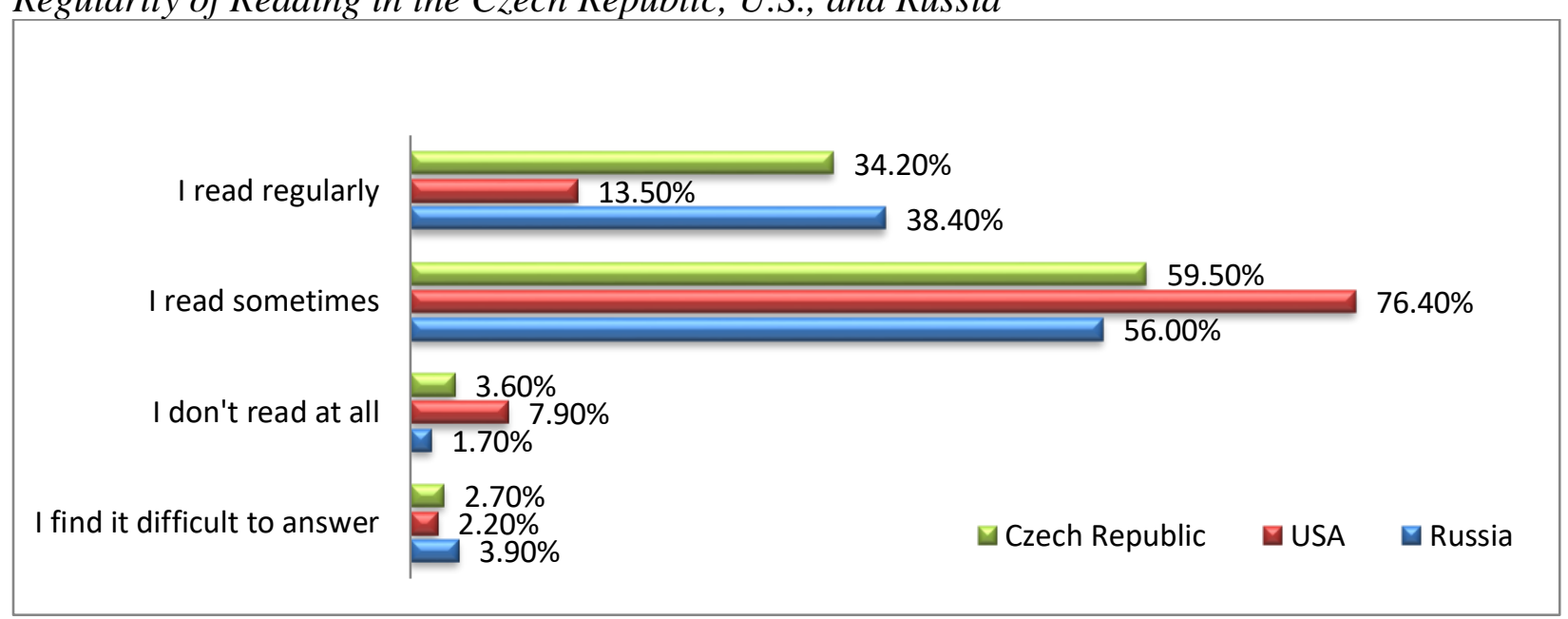

Results of answers to the question "What are your main motives for reading?" are presented in Figure 2.

\section{Figure 2}

The Main Motives for Reading in the Czech Republic, U.S., and Russia

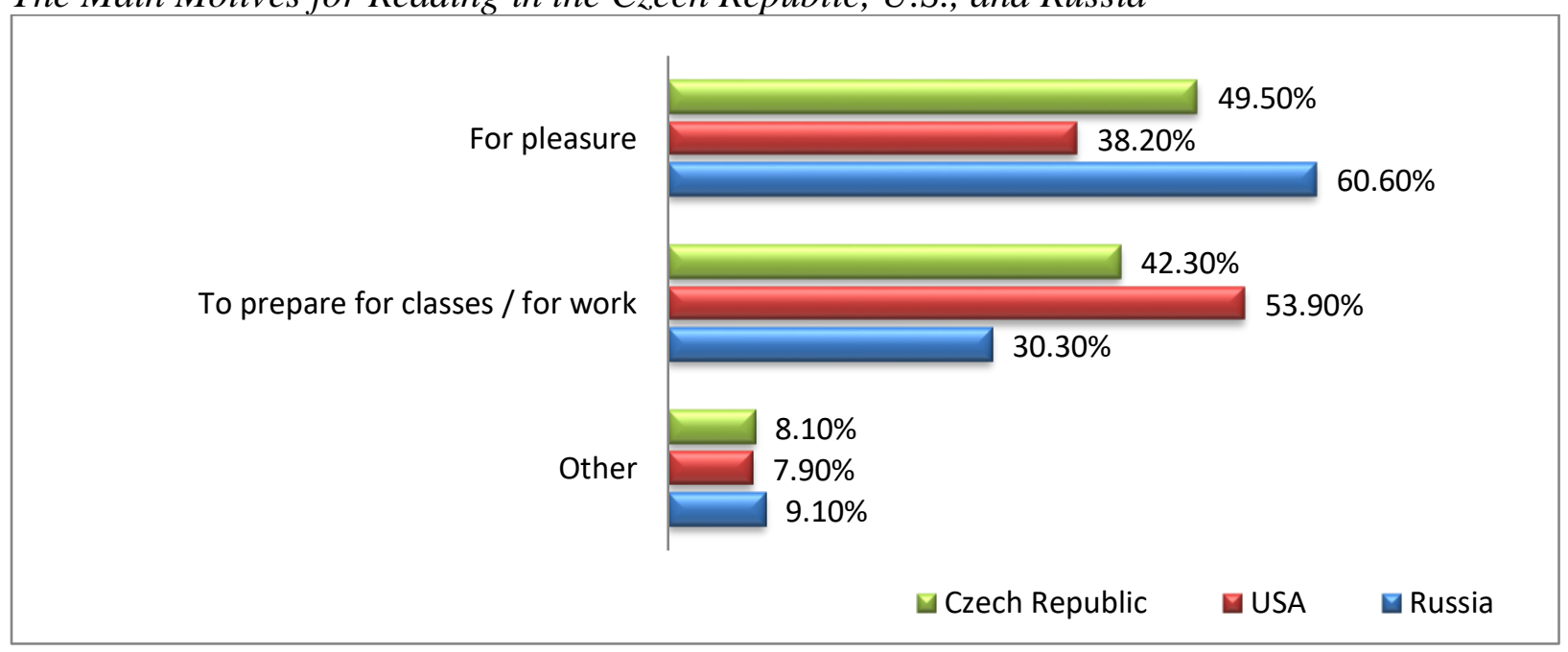

The results of the analysis of respondents' answers show that American youths read fiction less often than in Russia and the Czech Republic, and among Americans there are more young people who do not read at all. However, the answers to the question about the motives for reading show that the representatives of the United States read more often in order to prepare for classes and for work, more so than youths in Russia. Youths in the Czech Republic also read more for this purpose than in Russia. This suggests that Americans and Czechs are more motivated to acquire useful knowledge necessary for study and professional activity, while Russian youths read more for pleasure.

The next question we asked was about genre preferences. To the question "What kind of literary genres do you prefer in reading?" we got the following results: 
Among American youth, the first places were distributed as follows: the adventure genre took first place, as $55 \%$ of the total number of respondents chose it; second place was taken by the detective genre, preferred by $37 \%$ of the respondents; and third place went to the genre of fantasy, chosen by $29 \%$. The rest of the genres were chosen by less than $20 \%$ of the participants in our survey.

The favorites among the representatives of the Czech youth who took part in the study were the fantasy genre (59\%), the detective genre (49\%), and the adventure genre $(22 \%)$. The rest of the genres suggested in the questionnaire received less than $20 \%$ of the votes.

The reading preferences of Russian youth were distributed as follows: fantasy and adventure literature (50.7\% and 50.4\%, respectively), and the detective story and historical novel (36.3\% and $35.6 \%$, respectively).

To the question "Which reading format do you prefer?" we obtained the results presented in Figure 3. The diagram shows that the book is still the favorite format for the vast majority of young people in all three countries. However, fewer Russian youths prefer electronic and audio books than in the U.S. and Czech Republic.

Figure 3

Preferred Book Format in the Czech Republic, U.S., and Russia

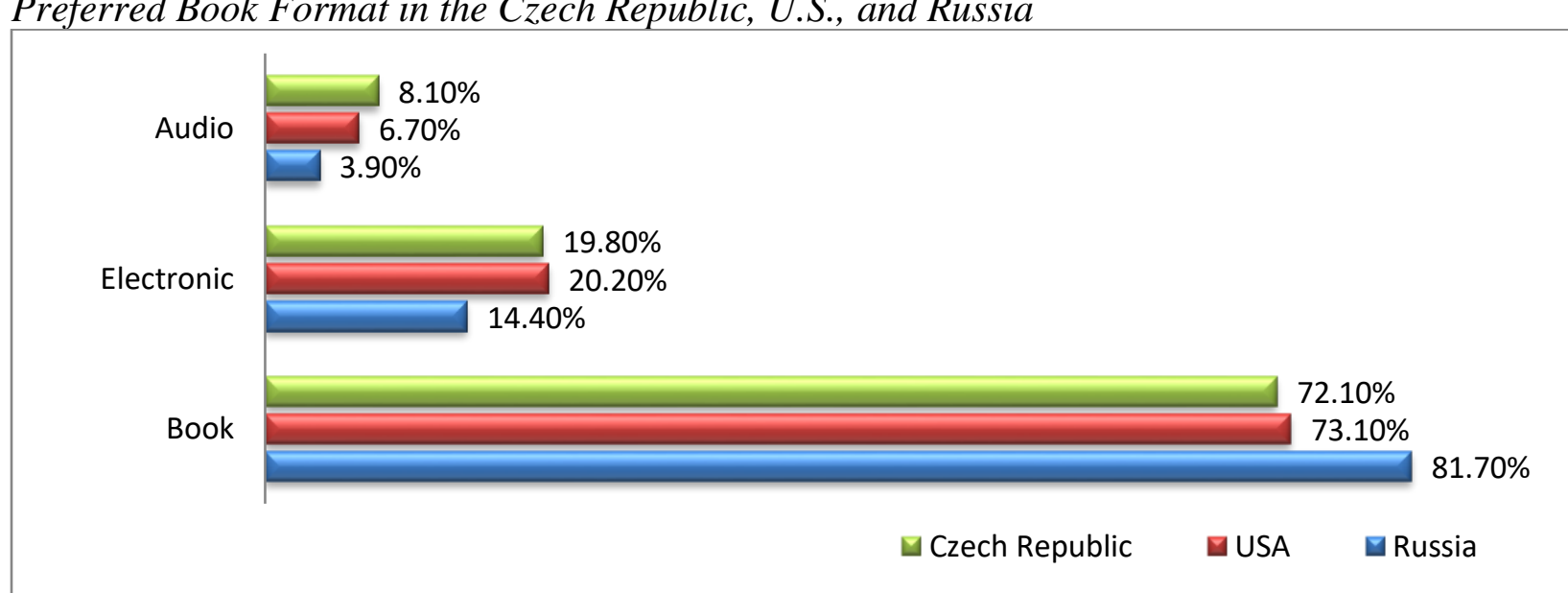

In our questionnaire, we asked the survey participants: "What book would you recommend everyone to read?" The leaders among all others in all three countries were J. K. Rowling's Harry Potter books, recommended by 14 people from the U.S., 7 from the Czech Republic, and 8 from Russia.

\section{Discussion}

According to Bailey (2016), the flowering of the literary-centered reading model in the United States occurred in the 1940s. During this period, reading was still the main form of leisure, young people turned to books in preparation for classes, and the traditional paper book dominated. The topic of leisure literature underwent changes, and two decades later, the youth readership was fascinated by fantasy literature, which may be explained by growing technological progress leading to, among other things, an increase in the number of publishing houses (U.S. Book Industry, 2019). The state actively participated in supporting the interest in reading among young people, and in the late 1970s, a federal government-funded reading research center was created. By the 1990s, e- 
books appeared, and the reading format expanded through the use of computer technology. Today, however, teenagers admit that they are "moving away" from the usual reading format only because the price of paper products is sharply rising in the United States (Graham, 2005; Smetannikova, 2017).

In 1992, a large-scale survey revealed the level of reading literacy of children in the U.S. (Elley, 1992). The respondents were 9-year-old and 14-year-old schoolchildren. Data was collected from 9,073 schools; 10,518 teachers and 210,059 students took part in the survey. The study made it possible to conclude that over 20 years (since 1970), the number of children reading sharply decreased (Elley, 1992; Gaffney \& Anderson, 2000).

In the Czech Republic in 2002, a PISA survey was conducted in 345 schools. It was attended by more than 7,000 children born in 1988. According to the results of the survey, it was revealed that $86 \%$ of schoolchildren read regularly and with pleasure, preferring the paper format of reading, $12 \%$ read irregularly, and only $2 \%$ fell into the group of "non-reading" children. The study also made it possible to draw a conclusion regarding the reading preferences of the young audience. The favorite genre of teenagers was stories and novels; only $5 \%$ of respondents chose fiction and fantasy (Janotová et al., 2017; Trávníček, 2008).

In Russia, the process of socioeconomic recovery took more time, so the literary-centered reading model became apparent only in 1980 (Kozyrev, 2004). If in the United States and the Czech Republic, the middle of the $20^{\text {th }}$ century is characterized by a renaissance of book publishing and an increase in the "reading activity" of the population persisting until the end of the century, then in Russia in the 1970s and 1980s there was a "boom in book-collecting," increasing the prestige of owning a home library. Historical novels and detective stories, particularly those by foreign authors, were popular. By the beginning of the $21^{\text {st }}$ century, the list of readers' preferences was replenished with works that, for ideological reasons, were not available to readers in the Soviet era. Among young people, the works of Mikhail Bulgakov, Vladimir Nabokov, and others, the so-called "new classics," are gaining special popularity. However, a certain decline in reading activity was observed already by the 1990s. Television, cinema, and theater became alternatives to reading. According to a study conducted in Russia in 1992-1997 (Zorkaya, 1998), which was attended by 10,000 people (including 5,000 people under the age of 25), the following was established: On average, the respondents watched television 3 hours a day. They spent 1.2 hours a day reading newspapers and 1.9 hours reading books, but they tried to read every day. The most active readers were people under age 25 , which is undoubtedly related to learning. Russian and foreign romance and history novels became favorites, followed by detective stories, adventure novels, and science fiction.

In recent studies, more and more often it comes to what and how young people read, which arouses interest in certain literary genres, fantasy in particular (Adams, 2020; Aleksandrov, 2001; Ammosov, 2005; Bell, 2010; Black, 2003; Brevnova, 2005; Campbell, 2010; Lerer, 2008; Pomogalova, 2006; Vasilieva, 2005; Vinogradova, 2003; Winterle, 2013), and what factors contribute to the formation of reading literacy and socialization of a young reader (Broeder \& Stokmans, 2013; Brownell \& Rashid, 2020; Chudinova, 2017; Morgan, 2015). The issue of reading naturally embraces ever wider layers of the cultural state of society, going far beyond the traditional approach. It is not surprising that librarians, sociologists, political scientists, culturologists, futurologists, and educators are concerned about the decline in the interest of the younger generation in books.

Often there are alarming notes about the future of "book culture in the information society." The question of whether the traditional book will be completely ousted from the information space or will coexist with new information and communication means remains controversial (Lensky, 
2011, p. 68). The change in the media environment entails fundamental shifts in the field of reading, opening up more and more attractive possibilities of the digital environment for young people (Velagić, 2014). According to forecasts of Russian researchers, in the coming years there will be a coexistence of books in paper and electronic formats, which seems obvious. At the same time, it is also obvious that "the role of national cultures and their fundamental constants" should not go to the periphery of public interests (Nazarov \& Kovalev, 2017, p. 93).

At the same time, it is advisable to pay attention to the reading priorities of the youth, to direct them in the right direction, to look for points of contact in the intercultural space, bringing a certain scale of values of a modern person to a kind of common denominator. The problem of the general deheroization of modern society, the reassessment of values, a failure in communication between generations, and the problem of self-identity (national and confessional) leads to young people looking for answers to questions in virtual reality, in a fantasy world, so it is no coincidence that the peak popularity of fantasy literature happened at the turn of the century. The turn of the century, as a rule, is accompanied by a certain "spiritual crisis," the search for moral guidelines (Krynski, 2019; Lafer \& Tarman, 2019). The change in the cultural paradigm, which entailed radical transformations in the economic and ideological structures of society, has led to fantasy becoming a multimedia phenomenon popular among young people, shifting the age limits of the potential reader. Fantasy literature leads among readers' preferences, starting from primary school age (Berges Puyo, 2020).

Researchers cite a wide range of representations of book culture in the contemporary Russian media landscape: network (original content) and digitized (version of printed materials) literature; electronic libraries and portals; traditional libraries in the digital format: electronic catalogues, remote access, interaction with readers on sites, etc.; literary forums and reading communities on social networks, book-tubing in various ways; online movie clubs, seminars, open lectures, web sites for discussion, webinars related to books and reading; professional and nonprofessional forms of recommendation of a book: sites of publishing houses and bookselling organizations, individual writers and other resources (Askarova \& Zubanova, 2018, p. 96). As can be seen from this sufficiently solid arsenal of forms of interaction between the media and the reader, it is difficult to choose the right "navigation." In the authors" opinion, this mission could be assigned, along with the family institution, to "literary pedagogy" as an integral pedagogical process of the directed development and formation of a cultural personality by means of literature (Jentgens, 2016).

\section{Conclusion}

The results of this study confirmed that the most widely read books include the Harry Potter novels. The "pedagogical potential" of this work is found at different levels of reading, which, if possible, should be taken into account by librarians, parents, and teachers, even at different age levels. In this regard, it seems appropriate to make this process manageable. Libraries, as before, are trying to solve these problems on their own, popularizing primarily the traditional paper book format. The international study of readers' culture of modern youth has confirmed the hypothesis that fantasy is not only one of the ways of socializing a person but also an instrument for building intercultural dialogue, an effective means of reader communication among representatives of various nations and nationalities living on the planet today. 


\section{References}

Adams, B. (2020). How English-Speaking Teachers Can Create a Welcoming Environment that Allows Students to Maintain and Utilize their Language through Translanguaging: A Qualitative Case Study. Journal of Culture and Values in Education, 3(2), 196-211. https://doi.org/10.46303/jcve.2020.20

Alexandrov, V. (2001). Harry Potter on the world stage: Who invented football, or Harry Potter at school and at home. New World, 7. http://magazines.russ.ru/novyi_mi/2001/7/aleks.html

Ammosov, Yu. (2005). Potter must die: The children's book was an epic, and the epic turned into a tragedy. Questions of Literature, 4. http://magazines.russ.ru/voplit/2005/4/amm9.html

Askarova, V. Ya., \& Zubanova, L. B. (2018). The study of children's and youthful reading in the era of digital reality: Current research and design strategies. Bulletin of the Moscow State and Project Strategies, 5(85), 93-102.

Bailey, A. (2016). Reading for children and youth in the USA in the 20th century. https://www.bl.uk/20th-century-literature/articles/fiction-for-children-in-the-first-40years-of-the-20th-century

Başok, E., \& Sayer, P. (2020). Language Ideologies, Language Policies and their Translation into Fiscal Policies in the U.S. Perspectives of Language Education Community Stakeholders. Journal of Culture and Values in Education, 3(2), 54-80. https://doi.org/10.46303/jcve.2020.13

Bekteshi, E., \& Xhaferi, B. (2020). Learning about Sustainable Development Goals through English Language Teaching. Research in Social Sciences and Technology, 5(3), 78-94. https://doi.org/10.46303/ressat.05.03.4

Bell, L. (2010). Baptizing Harry Potter. A Christian reading of J. K. Rowling. Hidden Spring, 219.

Berges Puyo, J. (2020). A value and character educational model: Repercussions for students, teachers, and families. Journal of Culture and Values in Education. https://doi.org/10.46303/jcve.2020.7

Black, S. (2003). The magic of Harry Potter: Symbols and heroes of fantasy. Children's Literature in Education, 34(3), 237-247.

Boshkova G., Shastina E., \& Shatunova O. (2018). The role of grandparents in the child's personality formation (on the material of children's literature). Journal of Social Studies Education Research, 9(2), 283-294.

Brevnova, Yu. S. (2005). Formation and development of a youth cult based on a literary work: On the example of a series of books by J. K. Rowling [Doctoral dissertation, Candidate of Cultural Studies].

Broeder, P., \& Stokmans, M. (2013). Why should I read? A cross-cultural investigation into adolescents' reading socialisation and reading attitude. International Review of Education, 59(1), 87-112.

Brownell, C., \& Rashid, A. (2020). Building bridges instead of walls: Engaging young children in critical literacy read alouds. Journal of Curriculum Studies Research, 2(1), 76-94. https://doi.org/10.46303/jcsr.02.01.5

Campbell, L. M. (2010). Harry Potter and the ultimate in-between: J. K. Rowling's portals of power. In D. E. Palumbo \& C. W. Sullivan (Eds.), Portals of power: Magical agency and transformation in literary fantasy (pp. 163-182).

Chudinova, V. P. (2017). Literacy and reading support: Experience from different countries. University Book, 3, 44-49. 
Elley, W. B. (1992). How in the world do students read?: IEA study of reading literacy. International Association for Evaluation of Educational Achievement, Vol. XIII.

Firestone, A., \& Clark, L. A. (2018). Harry Potter and convergence culture: Essays on fandom and the expanding Potterverse. McFarland \& Company.

Fortunati, L., \& Vincent, J. (2014). Sociological insights on the comparison of writing/reading on paper with writing/reading digitally. Telematics and Informatics, 31(1), 39-51.

Gaffney, J. S., \& Anderson, R. S. (2000). Trends in reading research in the United States: Changing intellectual currents over three decades. Handbook of Reading Research, 3, 53-74.

Garrone-Shufran, S., \& Tannebaum, R. (2020). Introduction to the Special Issue. Journal of Curriculum Studies Research, 2(2), i-iii. https://doi.org/10.46303/jcsr.2020.6

Gibbs, B. (2020). Critical teaching in classrooms of healing: Struggles and testimonials. Journal of Curriculum Studies Research, 2(1), 95-111. https://doi.org/10.46303/jcsr.02.01.6

Graham, P. A. (2005). Schooling America: How the public schools meet the nation's changing needs. Oxford University Press.

Gudova, M. Yu. (2015). Reading in the era of post-literacy: A cultural analysis. Doctors of Cultural Studies, Yekaterinburg.

Janotová, Z., Tauberová, D., \& Potužníková, E. (2017). Mezinárodní šetření PIRLS 2002: Národní zpráva. Praha: Česká školní inspekce (p. 5).

Jentgens, S. (2016). Lehrbuch literaturpädagogik. Eine einführung in theorie und praxis der literaturvermittlung. Beltz Verlag, Weinheim https://www.beltz.de/fileadmin/beltz/leseproben/978-3-7799-3330-4.pdf

Jeong, H. (2012). A comparison of the influence of electronic books and paper books on reading comprehension, eye fatigue, and perception. The Electronic Library, 30(3), 390-408.

Johnson, M. (2020). Serious with the Wordplay: Battle Rap as a Critical Literacy Site and Model. Journal of Culture and Values in Education, 3(2), 24-41. https://doi.org/10.46303/jcve.2020.11

Kozyrev, V. A. (2004). Humanitarian educational environment of the pedagogical university: Essence, model, design. Publishing House of the RGPU - A. I. Herzen.

Krynski, A. (2019). In a state of fragility: The compromised dignity of communities, indignation, and the incapacitation of public education. Journal of Culture \& Values in Education, 2(3), 1-24. https://doi.org/10.46303/jcve.03.02.1

Lafer, S., \& Tarman, B. (2019). Editorial 2019: Special issue. Journal of Culture \& Values in Education, 2(1), i-v. https://doi.org/10.46303/jcve.02.01.ed

Lehman, C., \& Welch, B. (2020). A Quantitative Investigation of Language Policy in International Schools in East Asia. Research in Educational Policy and Management, 2(2), 1-18. https://doi.org/10.46303/repam.2020.1

Lensky, B. V. (2011). The future of the book in the information age. Bulletin of Moscow State University - Ivan Fedorov, 3, 67-85.

Lerer, S. (2008). Children's literature. A reader's history, from Aesop to Harry Potter. The University of Chicago Press.

Masud, M. M. (2020). International Student Migration and Polymedia: The Use of Communication Media by Bangladeshi Students in Germany. Research in Social Sciences and Technology, 5(3), 95-110. https://doi.org/10.46303/ressat.05.03.5

Moody, R. (2020). Contextualizing "Practice\&quot;: Helping Pre-Service Teachers Unpack the Ideological and Sociopolitical Dimensions of Required Practices for Licensure. Journal Of Curriculum Studies Research, 2(2), 60-80. https://doi.org/10.46303/jcsr.2020.10 
Morgan, N. (2015). Improving child literacy in England. www.gov.uk/government/speeches/nicky-morgan-improving-child-literacy-in-england

Mozhaeva, G. V. (2015). Digital humanities: A digital turn in the humanities. Humanitarian Informatics, 9, 8-23.

Nazarov, M. M., \& Kovalev, P. A. (2017). Changing the media and modern reading practices. Sociological Research, 2(394), 84-95.

Morales, J., \& Bardo, N. (2020). Narratives of Racial Reckoning: Oppression, Resistance, and Inspiration in English Classrooms. Journal of Culture and Values in Education, 3(2), 138157. https://doi.org/10.46303/jcve.2020.17

Petrovskaya, E. (2012). "Technical Man": On the relationship of the internet and literature. Expert, 2, 96-98.

Pontier, R., Destro Boruchowski, I., \& Olivo, L. (2020). Dynamic Language Use in Bi/Multilingual Early Childhood Education Contexts. Journal of Culture and Values in Education, 3(2), 158-178. https://doi.org/10.46303/jcve.2020.18

Pomogalova, N. V. (2006). Fantasy and the socialization of personality (socio-philosophical analysis) [Doctoral dissertation, Philos. Sciences, Omsk].

Rubanova, T. D. (2018). Support for reading in the space of book social networks. Bulletin of Culture and the Arts, 3(55), 45-53.

Salinas-Vasquez, L., Varela, D., Martinez, M., \& Jones, D. (2020). A Comparative Study of the 21st Century Afterschool Center on Education in Elementary Schools in South Texas. Research in Educational Policy and Management, 2(2), 19-37. https://doi.org/10.46303/repam.2020.2

Shastina, E., Shatunova, O., Borodina, T., Borisov, A., \& Maliy, Y. (2018). The role of reading in the development of giftedness in the context of globalization and national identity. Journal of Social Studies Education Research, 9(1), 158-167.

Smetannikova, N. N. (2017). Teaching reading in a socio-political context (On the example of the United States of the second half of the XX-early XXI century). Bulletin of Culture and Arts, 1(49), 24-37.

Stacy, J., Fernández, Y., \& Reyes McGovern, E. (2020). El Instituto: Centering Language, Culture, and Power in Bilingual Teacher Professional Development. Journal of Culture and Values in Education, 3(2), 120-137. https://doi.org/10.46303/jcve.2020.16

Timberlake, M. (2020). Recognizing Ableism in Educational Initiatives: Reading between the Lines. Research in Educational Policy and Management, 2(1), 84-100. https://doi.org/10.46303/repam.02.01.5

Trávníček, J. (2008). Výzkum čtenářství. Příloha časopisu, 2, 2-39.

U.S. Book Industry. (2019). Statistics \& Facts. https://www.statista.com/statistics/222754/bookformat-used-by-readers-in-the-us/

Vasilieva, N. I. (2005). Folklore archetypes in modern mass literature: The novels of J. K. Rowling and their interpretation in the youth subculture [Ph.D. Dissertation, Nizhny Novgorod].

Velagić, Z. (2014). The discourse on printed and electronic books: Analogies, oppositions, and perspectives. An International Electronic Journal, 19(2), 619. http://www.informationr.net/ir/19-2/ paper619.html\#.Vs3CgU6AMrI

Vershitskaya, O. N. (2007). Information and communications technology and society. Nauka.

Vinogradova, O. V. (2003). Pedagogical conditions for increasing the efficiency of reading fantasy literature by adolescents: Abstract of thesis [Ph.D. Dissertation, Moscow].

$\mathrm{Vu}, \mathrm{T}$. (2019). Theoretical Constructs and Practical Strategies for Intercultural Communication. Journal of Curriculum Studies Research, 1(1), 43-53. https://doi.org/10.46303/jcsr.01.01.4 
Wilson, T. D. (2014). The e-book phenomenon: A disruptive technology. An International Electronic Journal, 19(2), 612.

Winterle, I. D. (2013). The phenomenon of incompleteness in the early works of J. R. R. Tolkien and the problem of the formation of the concept of fantasy [Ph.D. Dissertation, Nizhny Novgorod].

Zorkaya, N. (1998). Trends in the reading of Russians in the '90s: On the material of the polls of the VCIOM 1992-1997. Monitoring Public Opinion: Economic and Social Change, 3, 4449.

\section{Notes on Contributors}

Assoc. Prof. Bulent Tarman has more than 25 years of professional experience in the field of education. He earned his Ph.D. degree in Curriculum \& Instruction (social studies education), as well as a minor in Comparative and International Education at the Penn State University. He also holds a BA in History from Hacettepe University, Turkey, and an MEd. in social studies education at the University of Missouri, Columbia. His research interests include Social Studies Education, Teacher Education, Innovation in Education, Citizenship and Human Rights Education, Globalizing Education, Curriculum Development, Gender Issues in Education, ICT in Education, and Multiculturalism in Education.

Olga Vasilyevna Shatunova - head of Department of Education, Associate professor, $\mathrm{PhD}$ in Education. Kazan Federal University, Yelabuga Institute, Russian Federation, Department of Education, orcid.org/0000-0001-5832-3150. Research interests: art pedagogy, literary pedagogy, gaming technology in education, information technology in social work. E-mail: olgashat67@mail.ru

Galina Nikolayevna Bozhkova - associate professor, PhD in Philology. Kazan Federal University, Yelabuga Institute, Russian Federation, Department of Russian Language and Literature, orcid.org/0000-0001-7204-1504. Research interests: literary studies, history of Russian literature of the nineteenth century, children's literature, regional literature, literary pedagogy. Email: bozhkova.galina@mail.ru

Elena Mikhailovna Shastina - PArofessor, Doctor of Philology. Kazan Federal University, Yelabuga Institute, Russian Federation, Department of German Philology, orcid.org/0000-00019551-5469. Research interests: literature of German-speaking countries, literature of peoples of foreign countries, theoretical foundations of multilingual education, language of mass media. Email: shastina@rambler.ru 